\title{
Dragonfly and Damselflies at Gajahwong River in D.I. Yogyakarta Urban District
}

\author{
Mokhamad Nur Zaman*, Pratama Bimo Purwanto, Dharfan Ihlasul Iman, Farida, Astri Martha Sari, \\ Siti Lathifah Maulany, Muhamad Luthfika, Ngalimatur Rofiah, Giat Siti Halimah, Cahya \\ Faculty of Science and Technology, UIN Sunan Kalijaga, \\ J1. Marsda Adisucipto No 1 Yogyakarta 55281, Indonesia. Tel. +62-274-540971, Fax. +62-274-519739. \\ Email*: azamavicenna@gmail.com
}

\begin{abstract}
Dragonflies play an important role as a bio-indicator of environmental cleanliness and controller of other insect populations in nature. This study aims to reveal the population of dragonflies in the Gajah Wong river in urban areas in Yogyakarta. The method used is an exploratory method that is by exploring the Gajahwong river which is located between the southern ring road at Giwangan to the northern ring at Catur Tunggal. The results showed that 16 types of dragonflies and 9 types of damselflies were found there. The species which has the most number is Orthetrum Sabina with 253 individuals, and the less type is Gynacantha Subinterrupta, and Zyxomma Obtusum which only found one individual for each. Whereas for Damselflies most species is Pseudagrion Rubriceps with 255 and Ischnura senegalensis is the less which only has one individual.
\end{abstract}

Keywords: Damselflies, Dragonflies, Gajah Wong, Species individual

\section{INTRODUCTION}

Green Open Space has an important role for the habitat chosen by dragonflies (Hidayati 2008; Patty 2006). Urban areas are very vulnerable and have great potential for change for animals and plants that were before in an area. The existence of green open space helps to support biodiversity in densely populated areas. Human activity is very much and many who are concerned with personal interests alone, causing negligence will demand and keep biodiversity about places that are their top priority. Dragonflies are one of the animals that can fly with advanced (Hadi, 2013). Dragonflies can fly, dive in water, maneuver and even reverse, and fly 360 degrees using three wings and can reach speeds of 30 miles per hour. Dragonflies have four wings that are transparent and attached to the thorax. Estimated number of known types of dragonflies is 5000-6000 types of dragonflies (Susanti, 1998). Dragonflies are one of the animals that can fly with advanced (Hadi, 2013). Dragonflies can fly, dive in water, maneuver and even reverse, and fly 360 degrees using three wings and can reach speeds of 30 miles per hour. Dragonflies have four wings that are transparent and attached to the thorax. The estimated number of dragonflies known is 5000-6000 dragonflies (Susanti, 1998). Dragonfly diversity (Odonata) as a bioindicator of water quality describes the role of these animals in the surrounding environment. The sensitivity of Odonata nymphs to environmental changes makes them part of the most clearly visible bioindicator of environmental health. The reduced number of Odonata in an area can be an indication of changes in the quality of water and environmental health (Virgiawan et al, 2015).

Dragonflies are placed in the order of Odonata, which means the teeth are jawed at the end of the labium (lower lip) and there are sharp protrusions that resemble teeth. Odonata is divided into two sub orders, namely Anisoptera (ordinary dragonflies) and Zygoptera (needle dragonflies) (Siwi, 1991). Anisoptera has a fatter body characteristics and fly quickly, the head does not extend in a transverse place but is rounded, has a rear wing wider at the base than the front wing and the wing is stretched horizontally at rest. While the Zygoptera has a slimmer body and is smaller than an ordinary dragonfly. Flying slowly compared to ordinary dragonflies, the head extends in a transverse place having the front wing and rear wing of the same shape, both narrow at the bottom and when the rest is folded over the body together or slightly widened (Neldawati, 2011). Several studies of dragonfly species have been found in Indonesia, there are around 750 species. According to Ansori (2009), reported 75 species found around the rice fields of Bandung, West Java. Hanum, Salmah and Dahelmi (2013), reported as many as 91 species found in the Kandi Wildlife Park Area, Sawahlunto City, West Sumatra. Rohman (2012), reported 18 types of dragonflies found in the Kars Gunung Sewu District, Pracimantoro District, Wonogiri Regency, Central Java. The purpose of this study was to find the types of dragonflies found in the Gajah Wong river in the urban area of Yogyakarta. 


\section{MATERIALS AND METHODS}

\section{Study area}

The research was conducted in September 2018 and finished August 2019. Sampling was started on 08.00 was finished on 12.00 WIB located in urban district of Gajah Wong river start from southern ring road and end in northern ring road Yogyakarta Province, Indonesia.

\section{Procedures}

Data collection

Method of this research using cruise method (Rugayah \& Pratiwi, 2004) by exploring along the race which is has determined at least $100 \mathrm{~m}-200 \mathrm{~m}$ in every plot.

\section{Data analysis}

Specimens which found identified by field guide-book.

\section{RESULTS AND DISCUSSION}

The result of research showed that there were 6 families which total species were 25 species are found. Those species was Aeshnidae 1 species, Gomphidae 2 species, Libellulidae 13 species, Chlorocypidae 2 species, Coenagrionidae 5 species, Platicnemididae 2 species (see table 1.). The diversity of anisoptera sub-order was more diverse, that found 16 type where zygoptera found 9 type.

Table 1. Results of Dragonflies Species Data Collection in Gajah Wong River, Yogyakarta City Part.

\begin{tabular}{|c|c|c|c|c|c|c|c|c|c|}
\hline \multirow{2}{*}{ No } & \multirow{2}{*}{$\begin{array}{l}\text { Nama Famili } \\
\text { Nama Jenis }\end{array}$} & \multicolumn{8}{|c|}{ Lokasi } \\
\hline & & St 1 & St 2 & St 3 & St 4 & St 5 & St 6 & St 7 & St 8 \\
\hline & Aeshnidae & & & & & & & & \\
\hline \multirow[t]{2}{*}{1} & Gynacantha subinterrupta & - & - & - & - & - & - & - & $\mathrm{X}$ \\
\hline & Gomphidae & & & & & & & & \\
\hline 2 & Ictinogomphus decoratus (Selys, 1854) & - & $\mathrm{x}$ & - & - & - & - & - & - \\
\hline \multirow[t]{2}{*}{3} & Paragomphus reinwardtii (Selys, 1854) & - & - & - & $\mathrm{x}$ & - & $\mathrm{x}$ & - & $\mathrm{x}$ \\
\hline & Libellulidae & & & & & & & & \\
\hline 5 & Crocothemis servilia (Drury, 1770) & - & $\mathrm{x}$ & $\mathrm{x}$ & $\mathrm{x}$ & - & - & $\mathrm{x}$ & - \\
\hline 6 & Diplacodes trivialis (Rambur, 1842) & - & - & - & - & $\mathrm{x}$ & - & - & $\mathrm{x}$ \\
\hline 7 & Neurothemis ramburii (Brauer, 1866) & - & - & - & $\mathrm{x}$ & - & - & $\mathrm{x}$ & $\mathrm{x}$ \\
\hline 8 & Neurothemis terminata (Ris, 1911) & $\mathrm{x}$ & - & - & - & - & - & $\mathrm{x}$ & - \\
\hline 9 & Onycothemis culminicola & - & $\mathrm{x}$ & - & - & - & - & - & - \\
\hline 10 & Orthetrum testaceum (Burmeister, 1839) & $\mathrm{x}$ & $\mathrm{x}$ & - & - & $\mathrm{x}$ & $\mathrm{x}$ & $\mathrm{x}$ & $\mathrm{x}$ \\
\hline 11 & Orthetrum sabina (Drury, 1770) & $\mathrm{x}$ & $\mathrm{X}$ & $\mathrm{x}$ & $\mathrm{x}$ & $\mathrm{X}$ & $\mathrm{x}$ & $\mathrm{x}$ & $\mathrm{x}$ \\
\hline 13 & Potamarcha congener (Rambur, 1842 & - & - & - & $\mathrm{x}$ & $\mathrm{x}$ & - & - & $\mathrm{x}$ \\
\hline 14 & Rhodothemis rufa (Rambur, 1842) & - & $\mathrm{x}$ & $\mathrm{x}$ & $\mathrm{x}$ & - & - & - & $\mathrm{x}$ \\
\hline 15 & Tholymis tillarga (Fabricius, 1798) & - & - & - & $\mathrm{x}$ & - & - & $\mathrm{x}$ & $\mathrm{x}$ \\
\hline \multirow[t]{2}{*}{16} & Tetrathemis irregularis & - & - & - & - & - & $\mathrm{x}$ & - & $\mathrm{x}$ \\
\hline & Chlorocyphidae & & & & & & & & \\
\hline 17 & Heliocypha fenestrata (Burmeister, 1839) & - & - & - & - & - & $\mathrm{x}$ & $\mathrm{x}$ & $\mathrm{x}$ \\
\hline \multirow[t]{2}{*}{18} & Libellago lineata (Burmeister, 1839) & $\mathrm{x}$ & $\mathrm{X}$ & $\mathrm{x}$ & $\mathrm{x}$ & $\mathrm{x}$ & $\mathrm{x}$ & $\mathrm{x}$ & $\mathrm{x}$ \\
\hline & Coenagrionidae & & & & & & & & \\
\hline 19 & Agriocnemis femina (Brauer, 1868) & $\mathrm{x}$ & - & - & - & - & - & - & - \\
\hline 20 & Ischnura senegalensis (Rambur, 1842) & - & $\mathrm{x}$ & - & - & - & - & - & - \\
\hline 21 & Pseudagrion microcephalum (Rambur, 1842) & $\mathrm{X}$ & - & - & - & - & - & - & - \\
\hline 22 & Pseudagrion pruinosum (Burmeister, 1839) & $\mathrm{X}$ & $\mathrm{x}$ & $\mathrm{x}$ & $\mathrm{x}$ & $\mathrm{x}$ & $\mathrm{x}$ & $\mathrm{x}$ & $\mathrm{X}$ \\
\hline \multirow[t]{2}{*}{23} & Pseudagrion rubriceps (Selys, 1876) & $\mathrm{x}$ & $\mathrm{x}$ & $\mathrm{x}$ & $\mathrm{x}$ & $\mathrm{x}$ & $\mathrm{x}$ & $\mathrm{x}$ & $\mathrm{x}$ \\
\hline & Platycnemididae & & & & & & & & \\
\hline 24 & Copera marginipes (Rambur, 1842) & - & - & - & $\mathrm{X}$ & $\mathrm{X}$ & $\mathrm{x}$ & $\mathrm{X}$ & $\mathrm{x}$ \\
\hline
\end{tabular}

Keterangan:

St 1 Gadjah Wong Edu Park,-Pandeyan

St 2 Location of IPAL SGM-Balirejo fishery bridge

St 3 Balirejo-Timoho railroad bridge

St 4 Railway-side bridge futsal UIN-side SC (Student Center)

St 5 Affandi Bridge - Central Papringan Bridge

St 6 Middle Papringan Bridge - DAM Nologaten

St 7 Nologaten Bridge WH (Wahid Hasyim)-Rusunawa PU Nologaten Bridge

St 8 Selokan Mataram-Northern Ringroad

$\mathrm{X}$ Be discovered

- Not found 


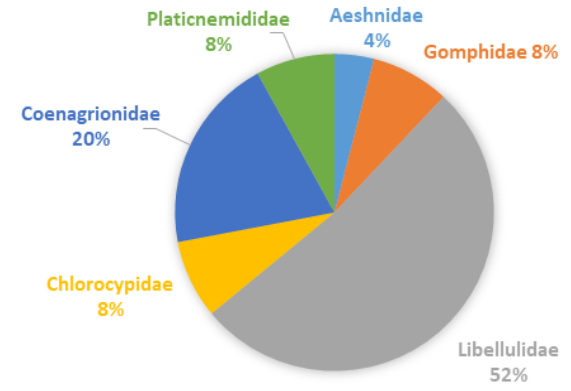

Figure 1. Prosentase of dragonfly and damselflies family in Gajah Wong River.

The most dominant species is Orthetrum sabina which the number of species was found 253, and the last type is Gynacantha subinterrupta, and Zyxomma obtusum which only found one individual for each. Whereas for Damselflies most species is Pseudagrion rubriceps with 255 and Ischnura senegalensis is the less which only has one individual. There are found some javanese endemic when collecting data. Those are Paragomphus reinwardtii from sub-order Anisoptera and $\mathrm{H}$. fenestrate. From sub-order Zygoptera.

\section{Discussion}

Figure 2. showed the number of dragonfly in every station which observed, the biggest number who observed in 7 station (Nologaten Bridge WH (Wahid Hasyim)-Rusunawa PU Nologaten Bridge), followed 4 station (Railway-side bridge futsal UIN-side SC (Student Center)), followed 3 station (Balirejo-Timoho railroad bridge), followed 5 station (Affandi Bridge-Central Papringan Bridge), followed 3 station (Location of IPAL SGM-Balirejo fishery bridge), followed 8 station (Selokan Mataram-Northern Ringroad), followed 6 station (Middle Papringan Bridge-DAM Nologaten) and 1 station (Gadjah Wong Edu Park until Pandeyan).

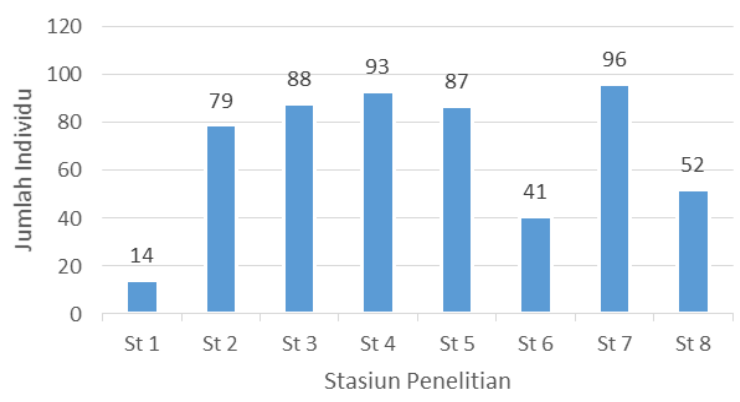

Figure 2. Number of dragonfly and damselflies individual in Gajah Wong River.

The distribution of dragonfly in every station can see the diagram on figure 3 . Based on the diagram, the highest number found of dragonfly in 8 station were 16 type. This number included on 21,9\% total amount of 73 dragonflies in Yogyakarta Province (Setiyono, et al., 2017). It means 8 station located along Gadjah Wong river in Selokan Mataram until Nothern Ringroad becoming one of selected habitus. Based on field observation, on riparian section still found much of vegetation, so it could support self-purification of pollution when entering the part of river. This is directly proportional to the need for the habitus of dragonfly for breeding, due to availability of clean water. Vegetation needed for dragonfly as resting area, waiting female coming weather waiting males coming for devoured. Whether the less number diversity of dragonfly were on 3rd station (Balirejo bridge until Timoho railway bridge) and 6th station (Middle Papringan Bridge - DAM Nologaten) every station only 9 species. The presence of dragonfly in a certain place influenced by many factor abiotic even biotic such type of habitus and species of vegetation around them which influence availability of food for them (McPeek, 2008).

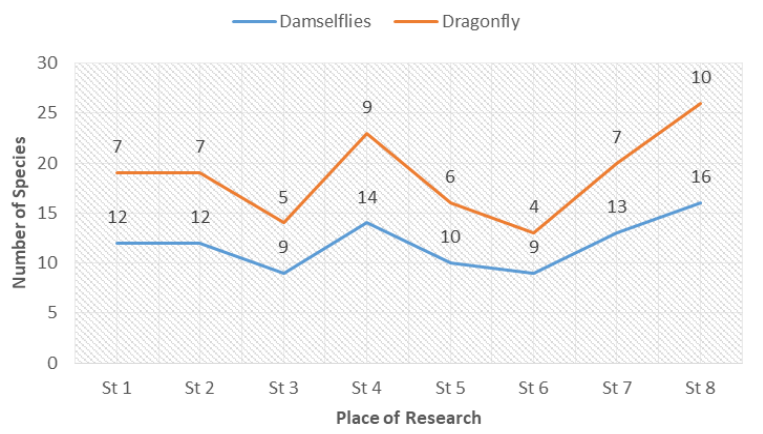

Figure 3. Number of dragonfly and damselflies species in Gajah Wong River.

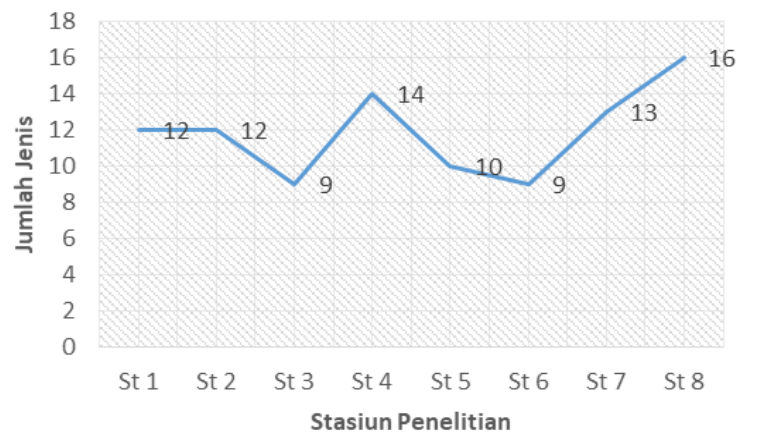

Figure 4. Total Number of dragonfly and damselflies species in Gajah Wong River.

The research there are common type of dragonflies can be found on all station, Orthetrum sabina. Amount of Orthetrum Sabina reached 235, the highest number compared to other species. This was included cosmopolit dragonfly due to could find easily in any habitus of dragonfly up to highest of $2500 \mathrm{~m} \mathrm{dpl}$ and very tolerant of environmental changing (Lieftinck, 1954). In addition, and main point of this research are found Javanese endemic species in urban district Gadjah Wong river those are Paragomphus reinwardtii, from sub-order Anisoptera in 4,6, and 8 station and Heliocypha fenestrate from sub-order Zygoptera in 6,7, and 8 station. 


\section{CONCLUSION}

The results showed that 16 types of dragonflies and 9 types of damselflies were found there. The species which has the most number is Orthetrum Sabina with 253 individuals, and the less type is Gynacantha Subinterrupta, and Zyxomma Obtusum which only found one individual for each. Whereas for Damselflies most species is Pseudagrion Rubriceps with 255 and Ischnura senegalensis is the less which only has one individual.

\section{ACKNOWLEDGEMENTS}

Thanks to Waterforum Kalijogo Study Club as the organization to collect database dragonfly and damselflies in Yogyakarta.

\section{REFERENCES}

Ansori I. 2008. Keanekaragaman Nimfa Odonata (Dragonglies) di Beberapa Persawahan Sekitar Bandung Jawa Barat. Jurnal Exacta 6(2): 42-52.

Budiman, M. A. K. (2014). Potensi pengembangan wisata birdwatching di wanawisata curug Cipendok Banyumas Jawa Tengah. [Skripsi]: IPB

Herlambang A. E. N, Mochamad H, Udi T 2016. Struktur Komunitas Capung di Kawasan Wisata Curug Lawe Benowo Ungaran Barat. Bioma. 18 (1) : 70-78

Diniarsih, S. (2016). Studi Mikrohabitat dan Populasi Capung Endemik Jawa Anggota Genus Drepanosticta (Odonata: Platystictidae) di Gunung Ungaran, Jawa Tengah. [Tesis]. Universitas Gadjah Mada Yogyakarta

Dow, R.A. (2009). Drepanosticta sundana. The IUCN Red List of Threatened Species. Version 2014.2. <www.iucnredlist.org>. Downloaded on 06 August 2014.

E.P. Odum .1999. Dasar - dasar ekologi, Yogyakarta.: UGM press.ch.3, pp. 178-180

Hidayati SNI. 2008. Keanekaragaman dan Aktivitas Capung (Ordo: Odonata) di Kebun Raya Bogor. [Skripsi]. Institut Pertanian Bogor, Bogor.

Hadi, MS. 2013. Capung, Predator Paling Hebat di Kerajaan Hewan https://tekno.tempo.co/read/news/2013/04/02/061470781/capu ng-predator-paling-hebat-di-kerajaan-hewan-- Diakses tanggal 21 November 2019 pukul 02.04.

Hanum, S.O., Salmah, S. dan Dahelmi. 2013. Jenis-jenis Capung (Odonata) di Kawasan Taman Satwa Kandi Kota Sawahlunto, Sumatera Barat. Jurnal Biologi 2(1): 71-76.

Johansson, F, Mikolajewski, D. J. 2008. Evolution of Morphological Defences. Aguilar, A.C. (eds). Dragonflies and Damselflies: Model Organisms for Ecological and Evolutionary Research. Oxford University Press Inc. New York

McPeek, M. A. 2008. Ecological Factors Limiting The Distributions and Abundances of Odonata. Aguilar, A.C. (eds). Dragonflies and Damselflies: Model Organisms for Ecological and Evolutionary Research. Oxford University Press Inc. New York.

Neldawati. 2011. Jenis-jenis Capung (Odonata) Dikawasan Resort Gunung Tujuh Taman Nasional Kerinci Kabupaten Kerinci Propinsi Jambi. Skripsi. FMIPA Universitas Andalas Padang.

Patty, N. 2006. Keanekaragaman Jenis Capung (Odonata) di Situ Gintung Ciputat, Tangerang. Skripsi. Fakultas Sains dan Teknologi Universitas Negeri Syarif Hidayatullah Jakarta. Jakarta.

Rachman H.T., and Rohman, A. (2016). Dragonfly Diversity (Odonata) in Menoreh Karst Central Java-Yogyakarta. Int'l Journal of Advances in Agricultural \& Environmental Engg. (IJAAEE). Vol.3: 255-258.

Rohman, A. 2012. Keanekaragaman Jenis dan Distribusi Capung (Odonata) Dikawasan Kars Gunung Sewu Kecamatan Pracimantoro, Kabupaten Wonogiri, Jawa Tengah. Skripsi. Universitas Negeri Yogyakarta.

Siwi, S. S. 1991. Kunci Determinasi Serangga. Kanisius. Yogyakarta.

Subramanian, K.A. (2005). Dragonflies and Demselflies of Peninsular India-A Field Guide. A collaboration of centre for Ecological Science, Institute of Science, Bangalor and Indian Academy of Science

Susanti, S. 1998. Seri Panduan Lapangan Mengenal Capung. Puslitbang Biologi LIPI. Bogor.

Virgiawan C., Iin Hindun \& Sukarsono. 2015. Studi Keanekaragaman Capung (Odonata) sebagai Bioindikator Kualitas Air Sungai Brantas Batu-Malang Dan Sumber Belajar Biologi. Jurnal Pendidikan Biologi Indonesia. 1(2). 188-196. 